\title{
Fen Eğitimine Yönelik Öz-Yeterliğin Öğrenme Yaklaşımları ve Öğrenme-Öğretme Ortamına Yönelik Algılara Etkisinin İncelenmesi
}

\author{
Doç. Dr. Neslihan Ültay ${ }^{1}$ \\ Doç. Dr. Necla Dönmez Usta ${ }^{2}$ \\ Doç. Dr. Eser Ültay ${ }^{3 *}$
}

Gelis tarihi: 27.02 .2020

Kabul tarihi: 17.04.2020

\section{Atıf bilgisi:}

IBAD Sosyal Bilimler Dergisi

Sayı: $8 \quad$ Sayfa: 1-13

Yıl: 2020 Dönem: Güz

This article was checked by Turnitin. Similarity Index 14\%

Bu makalede araștırma ve yayın etiğine uyulmuştur.

${ }^{1}$ Giresun Üniversitesi, Türkiye, neslihanultay@gmail.com, ORCID ID 0000-0002-9783-0486

2Giresun Üniversitesi, Türkiye, necladonmezusta@gmail.com,

ORCID ID 0000-0002-8075-7446

${ }^{3}$ Giresun Üniversitesi, Türkiye, eserultay@gmail.com,

ORCID ID 0000-0001-6839-6361

\footnotetext{
* Sorumlu yazar
}

ÖZ

Çalışmanın temel amacı; okul öncesi öğretmen adaylarının fen eğitimine yönelik özyeterliklerinin, öğrenme yaklaşımlarının ve öğrenme-öğretme ortamına yönelik algılarının incelenmesidir. Çalışma, ilişkisel tarama modeli kullanılarak yürütülmüştür. Çalışmanın örneklemini Doğu Karadeniz Bölgesi’ndeki bir devlet üniversitesinin Eğitim Fakültesi Okul Öncesi Öğretmenliği 1., 2., 3. ve 4. sınıflarında öğrenim görmekte olan 384 okul öncesi öğretmeni adayı oluşturmaktadır. Araştırmada veri toplama aracı olarak "Fen eğitimine yönelik özyeterlik ölçeği", "Öğrenme yaklaşımları ölçeği" ve "Ö̆ğrenme-öğretme ortamına yönelik algı ölçeği”" kullanılmıştır. Araştırmanın bulguları dikkate alındığında, okul öncesi 3. ve 4. sınıf öğretmen adaylarının fen öz-yeterliklerinin 1. sınıf öğretmen adaylarına oranla daha yüksek olduğu bulunmuştur. Araştırmadan elde edilen bir diğer sonuç da okul öncesi öğretmen adaylarının öğrenme yaklaşımlarının "derinlemesine" alt boyutunun 1. sinıflar lehine anlamlı derecede yüksek olduğu bulunmuştur. Sınıf seviyesi arttıkça derinlemesine öğrenme yaklaşımlarını tercih edenlerin sayısı azalmaktadır. Ayrıca öğrenme yaklaşımlarının "stratejik" alt boyutu için de yine 1. ve 2. sınıflar lehine anlamlı fark çıkmıştır. Öğrenme yaklaşımlarının "yüzeysel" alt boyutu için sinıf seviyelerine göre anlamlı bir farklılaşma görülmemiştir. Araştırmanın ulaştı̆̆ bir diğer sonuç da, okul öncesi öğretmen adaylarının sınıf seviyelerine göre öğrenme-öğretme ortamına yönelik algıları arasında 1. ve 2. sinıflar lehine farkın bulunması ve sınıf seviyeleri arttıkça öğretmen adaylarının öğrenme-öğretme ortamına yönelik algı puanlarının gittikçe düşmesidir. Araştırmanın dördüncü alt probleminden elde edilen sonuç ise okul öncesi öğretmen adaylarının fen eğitimine yönelik öz-yeterlikleri ile öğrenme yaklaşımlarını tercih etmeleri arasında orta düzeyde pozitif yönlü bir ilişkinin olmasıdır. Ayrıca okul öncesi öğretmen adaylarının fen eğitimine yönelik özyeterlikleri ile öğrenme-öğretme ortamına yönelik algıları arasında da öğrenme yaklaşımlarına oranla daha düşük yine pozitif yönlü bir ilişki bulunmuştur. Okul öncesi öğretmen adaylarının öğrenme yaklaşımlarını tercih etmeleri ise öğrenmeöğretme ortamına yönelik algıları ile daha yüksek oranda ilişkili çıkmıştır.

Anahtar Kelimeler: Fen Eğitimine Yönelik Öz-Yeterlik, Okul Öncesi Öğretmen Adayları, Öğrenme-Öğretme Ortamına Yönelik Algı, Öğrenme Yaklaşımları 


\title{
Investigation of the Effects of Self-Efficacy for Science Education on Learning Approaches and Perceptions of Learning-Teaching Environment
}

\author{
Assoc. Prof. Dr. Neslihan Ültay ${ }^{1}$ \\ Assoc. Prof. Dr. Necla Dönmez Usta ${ }^{2}$ \\ Assoc. Prof. Dr. Eser Ültay ${ }^{3 *}$
}

First received: 27.02 .2020

Accepted: 17.04 .2020

\section{Citation:}

IBAD Journal of Social Sciences

Issue: 8

Pages: 1-13

Year: 2020

Session: Fall

This article was checked by Turnitin. Similarity Index 14\%

\section{${ }^{1}$ Giresun University, Turkey, neslihanultay@gmail.com, \\ ORCID ID 0000-0002-9783-0486}

2Giresun University, Turkey, necladonmezusta@gmail.com, ORCID ID 0000-0002-8075-7446

${ }^{3}$ Giresun University, Turkey, eserultay@gmail.com,

ORCID ID 0000-0001-6839-6361

* Corresponding Author

\begin{abstract}
The main purpose of the study was to determine the preschool teacher candidates' self-efficacy towards science education, learning approaches and perceptions of the learning-teaching environment. The study was conducted using relational survey model. The sample of the study consists of 384 preschool teacher candidates who were studying in $1^{\text {st }}, 2^{\text {nd }}, 3^{\text {rd }}$ and $4^{\text {th }}$ grades of Preschool Education of Faculty of Education in a state university in the North East of Turkey. In the research, "selfefficacy scale for science education", "learning approaches scale" and "perception scale for learning-teaching environment" were used as data collection tools. When the findings of the study were taken into consideration, it was found that $3^{\text {rd }}$ and $4^{\text {th }}$ grade pre-service teacher candidates' of science self-efficacy was higher than $1^{\text {st }}$ grade pre-service teachers. Another result obtained from the study was that the "indepth" sub-dimension of learning approaches scale of pre-school teacher candidates' was significantly higher in favor of $1^{\text {st }}$ grade teacher candidates. As class level increases, the number of those who prefer "in-depth" learning approaches decreases. There was also a significant difference in favor of $1^{\text {st }}$ and $2^{\text {nd }}$ grades for the "strategic" sub-dimension of learning approaches. For the "superficial" subdimension of learning approaches scale, no significant difference was observed according to grade levels. Another result reached by the study was that there was a difference between preschool teacher candidates' perceptions of learning-teaching environment in favor of $1^{\text {st }}$ and $2^{\text {nd }}$ grades and as the grade levels increase, the perception scores of prospective teachers towards learning-teaching environment decrease gradually. The fourth sub-problem of the study was that there was a moderate positive relationship between preschool teacher candidates' self-efficacy towards science education and learning approaches. Furthermore, a lower positive correlation was found between preschool teacher candidates' self-efficacy towards science education and their perceptions about learning-teaching environment compared to learning approaches. Preschool teacher candidates' preference for learning approaches was more correlated with their perceptions about the learningteaching environment.
\end{abstract}

Keywords: Self-Efficacy Towards Science Education, Preschool Teacher Candidates, Perceptions About The Learning-Teaching Environment, Learning Approaches 


\section{GİRIŞ}

Eğitim sisteminin en önemli bileşenlerinden biri kuşkusuz öğretmenlerdir. Öğretmenlerin gelișen ve değișen dünyaya ayak uydurabilecek bireyler yetiștirebilmeleri onların öz-yeterlik inançları ile doğrudan ilişkilidir. Öğretmenlerin herhangi bir konu/kavram ile ilgili sahip oldukları bilgiyi aktarabilmek için; konuya olan hâkimiyetleri, yetenekleri ve davranışları kendilerinde bulundurabilme derecesi alan yazında öz-yeterlik olarak tanımlanmaktadır (Compeau ve Higgins, 1995; Gürcan, 2005; Khodarahimi, 2010). Öz-yeterliği yüksek olan öğretmenlerin mesleki doyumlarının da yüksek olduğu belirtilmektedir (Skaalvik ve Skaalvik, 2010; Khan, Fleva ve Qazi, 2015). Öğretmen öz-yeterliği öğrenme ortamındaki öğretimin kalitesini ve sürdürülebilirliğini de dinamikleştirmektedir (Azar, 2010). Öğrenme ortamının temel yap1 taşı olan öğretmenin öz-yeterliliği birçok araştırmanın da konusu olmuştur (TschannenMoran, Woolfolk-Hoy ve Hoy, 1998; Woolfolk-Hoy ve Spero, 2005; Toptaş ve Gözel, 2017; Bahadır, Dikmen, Akmençe, Şimşek ve Tuncer, 2019; Ocak ve Karakuş, 2019). Bazı araştırmalarda (Goddard, Hoy ve Woolfolk-Hoy, 2000) öğretmen öz-yeterliğinin öğrenme ortamındaki öğrenen başarıs1 ile doğrudan ilişkili olduğu sonucuna varılmıştır. Öğretmen ya da öğretmen adayı öz-yeterliklerinin akademik başarıyı yordama gücüne (Bahar, 2019), bilimsel araştırmaya (Akçöltekin, 2019), sınıf yönetimi dersine (Ekici, 2008) ve sınıf yönetimi becerilerine (Çelik, 2019), zeka türlerine (Berkant ve Ekici, 2007) yönelik ilişkilerinin incelendiği ve fen eğitimine yönelik öz-yeterliklerin belirlendiği çalışmalar (Vural ve Hamurcu, 2008; Bahadır vd., 2019) da mevcuttur. Ayrıca öğretmenlerin sahip oldukları öz-yeterliklerine dayalı olarak fen etkinliklerine yer vermeleri (Dönmez Usta ve Ültay, 2017) fen etkinliklerine ayrılan zamanın fen eğitimi öz-yeterlik becerileri ile ilişkili olduğu belirtilmektedir. Fen eğitimine yönelik öz-yeterliği yüksek olan bir öğretmen, öğrencilerinin fen bilimlerine yönelik bakış açılarında farklılıklar oluşturabilir. Okul öncesi öğretmenleri çocukların hayatta karşılaştıkları ilk öğretmenleri olması sebebiyle onların hayatında ayrı bir öneme sahiptir. Okul öncesi öğretmenlerinin fen konularına olan yaklaşımları, tutumları ve çeşitli yöntem ve tekniklerle bu bilgileri öğrencilere aktarabilmeleri onların sahip oldukları fen bilgilerinin düzeyi ile doğrudan ilişkilidir. Ancak yapılan bazı çalışmalar okul öncesi öğretmenlerinin kendilerini fen konularında bilimsel anlamda yetersiz hissettiklerini göstermektedir (Ayvac1, Devecioğlu ve Yiğit; 2002; Özbey ve Alisinanoğlu, 2008; Ültay ve Can, 2015).

Fen bilimlerine ilgi duyan bir öğrencinin temel eğitimi sırasında okul öncesi öğretmenlerinin öz-yeterliği yüksek ve teşvik edici olması, öğrencilerin merak, keşfetme ve yaratıcılıklarını geliştirilebilmesi bakımından önemli bir adımdır (Ültay ve Ültay, 2015; Gül ve Özay Köse, 2017; Ültay, Ültay ve Çilingir, 2018, 2019). Bu adım ayrıca diğer alanlardaki yaratıcılıklarını ve ileri düşünme becerilerini de önemli ölçüde etkileyebilir (Orkunoğlu, 2016). Bu doğrultuda geleceğin temel eğitimini önemli ölçüde şekillendirecek olan okul öncesi öğretmen adaylarının fen eğitimine yönelik öz-yeterliklerin belirlenmesi mevcut durumun ortaya konulması ve bu durumun değerlendirilerek gelecek çalışmaların şekillendirilmesi açısından da oldukça önemli olduğu söylenebilir.

Öğretmenlerin ya da öğretmen adaylarının fen eğitimine yönelik öz-yeterliğin ya da mesleki özyeterliklerinin, öğrenme yaklaşımları ve öğrenme-öğretme ortamına yönelik algıları ile ilişkili olduğu düşünülmektedir (Büyüktanır, 2014). Bu noktadan hareketle alan yazında, sahip olunan öz-yeterliğin öğrenme yaklaşımı, kaygı, tutum, algı, başarı gibi değişkenler ile incelenmesi gerektiği şeklinde öneriler bulunmaktadır (Kotaman, 2008). Öğretmen adaylarının öğrenme ortamlarındaki fen eğitimine yönelik tercih ettikleri öğrenme yaklaşımlarının öz-yeterlikleri ile ilişkisinin belirlenmesi ve öğrenme ortamlarındaki mevcut durumun niteliğinin ortaya konulmasının gerekli olduğu da düşünülmektedir (Biggs, 1987). Öğretmenlerin tercih ettikleri öğrenme yaklaşımlarının öğrencilerin akademik başarılarını, tutumlarını, motivasyonlarını ve öz-yeterliklerini etkileyebilir.

Marton ve Saljo 1976 yılında (akt. Ekinci, 2008) yapmış oldukları çalışmalarında öğrenme yaklaşımlarını genel olarak iki grupta toplamışlardır: Derinlemesine ve yüzeysel öğrenme yaklaşımları. Marton ve Saljo öğrencilere vermiş oldukları bilimsel bir makaleyi okumalarını istemişler, ardından onlara bazı sorular yöneltmişlerdir. Öğrencilerin sorulara cevap verme biçimlerinden öğrenme süreçlerini öncelikle derinlemesine ve yüzeysel olarak ikiye ayırmışlardır. Derinlemesine öğrenme yaklaşımında ögrenenler konuyu daha uzun süre belleklerinde tutarlar, diğer konular arasında bağlantılar kurarlar ve 
üst düzey bilişsel becerilerini kullanırlar. Yüzeysel öğrenme yaklaşımı ise öğrenenlerin öğrenmeleri gereken bilgiyi ezberledikleri, üst düzey bilişsel becerileri kullanmadıkları bir öğrenme yaklaşımıdır (Ramsden, 2000). Daha sonra birçok araştırmacının yapmış oldukları çalışmalar bu sonuçları destekler nitelikte olmuştur ancak sonradan yapılan çalışmalar derinlemesine ve yüzeysel öğrenme sürecine stratejik öğrenme sürecinin varlığını da eklemişlerdir. Stratejik öğrenme yaklaşımı ise iyi not almayı ve başarılı olmayı hedefleyen bir öğrenme yaklaşımıdır. Böylece öğrenme yaklaşımları alan yazında genel olarak üç başlık altında incelenmektedir (Ekinci, 2008).

Alan yazında öğrenme yaklaşımları ile öz-yeterlik inançları arasındaki ilişkinin incelendiği birçok çalışma mevcuttur. Bu çalışmalardan bazılarında derinlemesine öğrenme yaklaşımı yüksek olan öğretmenlerin öz-yeterliklerinin de yüksek olduğu belirtilmiştir (Büyüktanır, 2014). Bu nedenle öğrencilerin temel fen eğitimini şekillendirilmesine ve gelecek fen eğitimlerine bakış açısı oluşturulmasına birincil kaynak olan okul öncesi öğretmenlerinin mesleğe başlamadan önce tercih ettikleri öğrenme yaklaşımlarının belirlenmesi önem taşımaktadır. Çalışma kapsamında öğretmen adaylarının belirlenen öğrenme yaklaşımlarının öz-yeterlik ile de ilişkisinin ortaya konulması öğrenmeöğretme süreçlerinin planlanması açısından da gerekli olduğu düşünülmektedir. Öğrenme yaklaşımlarının kişisel özellikler, kişilik özellikleri, geçmiş eğitim yaşantıları ve öğrenme-öğretme ortamının özelliklerinden etkilendiği bilinmektedir. Alan yazında öğrenme yaklaşımı tercihinde öğrenme-öğretme ortamının özelliklerinin belirleyici olduğu belirtilmektedir (Biggs, 1999; Fry, Ketteridge ve Marshall, 2003; Ekinci, 2008). Ramsden (2000) çalışmasında öğrenme yaklaşımlarının öğrenen ile öğrenme görevi arasında karşılıklı etkileşime dayalı olduğunu sonucuna varmıştır. Öğrenme ortamına ilişkin algı mı öğrenme yaklaşımlarını belirlemede etkili oluyor, yoksa yaklaşımlara göre mi ortam algılanıyor?" sorusunun odak olduğu çalışmada (Diseth, 2007) öğrenme yaklaşımı ile öğrenmeöğretme ortamına yönelik algının ilişkisi ortaya konulmaya çalışılmıştır. Çalışmalarda öğrenme-öğretme ortamına yönelik algının öğrenme yaklaşımını etkilediği belirlenmiştir (Kember ve Leung, 1998; Ekinci, 2008). Bu nedenle çalışma kapsamında fen eğitimine yönelik öz-yeterliğin yanı sıra öğrenme yaklaşımlarının belirlenmesinde öğrenme-öğretme ortamına yönelik algının da incelenmesi gerektiğine inanılmaktadır. Çalışma sonucunda da kısmen de olsa okul öncesi öğretmen adaylarının fen eğitimine yönelik öz-yeterliklerinin öğrenme yaklaşımları ve öğrenme-öğretme ortamına yönelik algılarının incelenmesi ile alana katkı sağlayacağı düşünülmektedir.

Yukarıdaki gerekçelerden yola çıkılarak oluşturulan çalışmanın temel amacı; okul öncesi öğretmen adaylarının fen eğitimine yönelik öz-yeterliklerinin, öğrenme yaklaşımlarının ve öğrenme-öğretme ortamına yönelik algılarının incelenmesidir. Çalışmada bu temel amacın yanında aşağıdaki sorulara cevap aranmaktadir:

1. Okul öncesi öğretmen adaylarının sınıf seviyelerine göre fen eğitimine yönelik öz-yeterlikleri arasında anlamlı bir fark var mıdır?

2. Okul öncesi öğretmen adaylarının sınıf seviyelerine göre öğrenme yaklaşımlarının alt boyutları (derinlemesine, stratejik ve yüzeysel) arasında anlamlı bir fark var mıdır?

3. Okul öncesi öğretmen adaylarının sınıf seviyelerine göre öğrenme-öğretme ortamına yönelik algiları arasında anlamlı bir fark var midır?

4. Okul öncesi öğretmen adaylarının fen eğitimine yönelik öz-yeterlikleri ile öğrenme-öğretme ortamına yönelik algıları ve öğrenme yaklaşımları arasında anlamlı bir fark var mıdır?

\section{YÖNTEM}

\section{Araştırmanın Modeli}

Okul öncesi öğretmen adaylarının fen eğitimine yönelik öz-yeterliklerinin, öğrenme yaklaşımlarının ve öğrenme-öğretme ortamına yönelik algılarının incelenmesinin amaçlandığı bu çalışma, tarama modellerinden ilişkisel tarama modeli (Karasar, 2007) kullanılarak yürütülmüşsür. Çalışmanın temel amacı doğrultusunda üç değişken arasındaki değişim ve derece incelendiğinden ilişkisel tarama modeli tercih edilmiştir. 


\section{Evren ve Örneklem}

Çalışmanın örneklemi okul öncesi öğretmenlerinin oluşturduğu evrenden tabakalı ve kolay ulaşılabilir örnekleme yöntemleri ile seçilen Doğu Karadeniz Bölgesi'ndeki bir devlet üniversitesinde 2018-2019 akademik yılı bahar yarııılında öğrenim görmekte olan toplam 384 okul öncesi öğretmeni adayıdır. $\mathrm{Bu}$ sayı literatürde yer alan değerlerin (Cohen, Manion ve Morrison, 2005) üstündedir. Çalışmanın örneklemi iki aşamada seçildiği için çok aşamalı olarak değerlendirilir (Büyüköztürk, Kılıç Çakmak, Akgün, Karadeniz ve Demirel, 2009). Tabakalı örnekleme aşamasında sınıf düzeyi örneklem birimi olurken, kolay ulaşılabilir örnekleme aşamasında ise okul öncesi öğretmen adayları örnekleme birimini oluşturmaktadır. Öğretmen adaylarının sınıf düzeylerine göre dağılımı Tablo 1'de yer almaktadır.

Tablo 1. Öğretmen adaylarının sınıf düzeylerine göre dağılımı

\begin{tabular}{ccc}
\hline Sinıf Düzeyi & Öğrenci Sayısı \\
\hline 1. & Sinif & 89 \\
2. & Sinif & 114 \\
3. Sinif & 93 \\
4. & Sinif & 88 \\
Toplam & 384 \\
\hline
\end{tabular}

Çalışmada öncelikle toplam 427 öğretmen adayına veri toplama araçları uygulanmıştır. Ancak veriler incelendiğinde; eksik veriler nedeniyle 43 öğretmen adayı veri setinden çıkarılmış ve 384 öğretmen adayının verileri değerlendirmeye alınmıştır.

\section{Veri Toplama Araçları}

Araştırmada kullanılan ölçekler aşağıda detaylıca açıklanmıştır.

Fen eğitimine yönelik öz-yeterlik ölçeği (FÖÖ): Araştırmada kullanılan FÖÖ Büyüktanır (2014) tarafından geliştirilmiş olup, ölçeğin orijinal adı "Okul öncesinde fen eğitimine yönelik öz-yeterlik ölçeğidir". Araştırmaci ölçeği geliştirmeden önce alan incelemesi yapmış, ardından da Okul Öncesinde Fen Eğitimi dersini almış 20 3.sınıf okul öncesi öğretmen adayına kendilerini ne kadar yeterli hissettikleriyle ilgili bir kompozisyon yazdırmıştır. Burada yer alan ifadelerden yola çıkılarak ölçekteki maddelere karar verilmiş olup, daha sonra geçerlik ve güvenirlik analizleri gerçekleştirilmiştir. Ardından ölçeğe son şekli verilmiş olup, bu araştırmada da ölçeğin son hali araştırmacının izni dahilinde kullanılmıştır.

Ölçekte 16 madde bulunmakta olup, beşli Likert tipinde derecelendirme için "her zaman, genellikle, sık sık, bazen ve hiçbir zaman" kategorileri kullanılmıştır. Ölçeğin güvenirliği için hesaplanan güvenirlik katsayısı (Cronbach alpha) 0.927 çıkmış olup, ölçek oldukça güvenilir bulunmuştur.

Öğrenme yaklaşımları ölçeği (ÖYÖ): Araştırmada kullanılan ÖYÖ Ekinci (2008) tarafından geliştirilmiş olup, "derinlemesine", "stratejik" ve "yüzeysel" olmak üzere üç alt boyuttan oluşmaktadır. İlk 18 madde "derinlemesine" alt boyunu, 19'dan 36. maddeye kadar "stratejik" alt boyutunu, son 18 madde ise "yüzeysel" alt boyutunu ölçen maddelerdir. Ölçek öğrenme yaklaşımlarının neler olduğunu ortaya koymaktan ziyade öğrencilerin bu yaklaşımlardan hangilerini tercih ettiklerini belirlemeye yönelik olarak geliştirilmiştir. Bu araştırmada da aynı amaçla kullanılmış olup, araştırmacıdan ölçeğin kullanımı ile ilgili gerekli izinler alınmıştır.

Ölçekte 54 madde bulunmakta olup, beşli Likert tipinde derecelendirme için "tam yansitıyor, çok yansitıyor, biraz yansıtıyor, az yansıtıyor, hiç yansıtmıyor" kategorileri kullanılmıştır. Ölçeğin bütününün güvenirliği için hesaplanan güvenirlik katsayısı (Cronbach alpha) 0.889 çıkmış olup, ölçek oldukça güvenilir bulunmuştur. Ölçeğin okul öncesi öğretmen adayları için yapılmış geçerli güvenirlik analizi Büyüktanır (2014) tarafından yapılmış olup, güvenirlik katsayısı derinlemesine alt boyutu için 0.84 , yüzeysel alt boyutu için 0.81 , stratejik alt boyutu için ise 0.88 bulunmuştur.

Öğrenme-öğretme ortamına yönelik algı ölçeği (ÖÖOÖ): Araştırmada kullanılan ÖÖOÖ yine Ekinci (2008) tarafından geliştirilmiş olup, ölçek öğrenci algılarına göre öğrenme-öğretme ortamının yüzeysel öğrenmeye mi anlamlı öğrenmeye mi götürecek özelliklere sahip olma derecesinin belirlenmesi amacı 
taşımaktadır. Araştırmacıdan ölçeğin kullanımı ile ilgili gerekli izinler alındıktan sonra bu araştırmada kullanılmıştır.

Ölçekte 31 madde bulunmakta olup, beşli Likert tipinde derecelendirme için "tam yansitıyor, çok yansitıyor, biraz yansitıyor, az yansitıyor, hiç yansıtmıyor" kategorileri kullanılmıştır. Ölçeğin okul öncesi öğretmen adaylarına uygulanmasıyla hesaplanan güvenirlik katsayısı (Cronbach alpha) 0.872 çıkmış olup, ölçek oldukça güvenilir bulunmuştur.

\section{Verilerin Analizi}

Araştırmadan elde edilen verilerin analizinde IBM SPSS v22 paket programı kullanılmıştır. Verilerin analizinde kullanılacak parametrik ya da parametrik olmayan testlerin tercihine ise verilerin normal dağılım yapıp yapmadığına ve verilerin varyanslarının homojenliğine göre karar verilmiştir. Buna göre, FÖÖ'den ve ÖYÖ'den elde edilen veriler normal dağ 11 m göstermesine rağmen, varyanslar homojen bulunmamıştır. Bu sebeple FÖÖ'nün ve ÖYÖ'nün analizinde parametrik olmayan testlerden çoklu karşılaştırmalar için Kruskal-Wallis testi, ikili karşılaştırmalar için ise Mann-Whitney U testi kullanılmıştır. ÖÖOÖ'den elde edilen veriler ise hem normal dağılım göstermekte olup, hem de varyanslar homojen bulunmuştur. Bu sebeple ÖÖOÖ'nün analizinde parametrik testlerden ilişkisiz örneklemler için Tek Yönlü Varyans Analizi (One-way ANOVA) kullanılmıştır. Ayrıca ÖÖOÖ’de olumsuz olan maddeler $(27,28,29,30$ ve 31 . maddeler) ters çevrilerek kodlanarak analizler yapılmıştır.

\section{Araştırmada Etik}

Araştırmaya dahil edilen öğretmen adaylarının veri toplama sürecinde toplanan verilerinin okuyucu ile paylaşımı konusunda rızaları alınmıştır. Ayrıca öğretmen adaylarının bazı demografik bilgilerinin de okuyucu ile paylaşılacağı açıkça belirtilerek onayları alınmış araştırmadan herhangi bir şekilde zarar görmeyecekleri belirtilmiştir (Cohen ve Manion, 1989; Drew, Hardman ve Hart, 1996). Uygulamalar ve veri toplama sürecinde araştırmacı ile öğretmen adayları arasında geçen bazı özel diyaloglar mahremiyet ve gizlilik ilkelerince araştırmaya yansıtılmamıştır. Bununla birlikte, araştırma etiği çerçevesinde veri toplama sürecine katılan öğretmen adaylarının isimleri gizli tutulmuştur.

\section{BULGULAR}

\section{Araştırmanın Birinci Alt Problemine Ait Bulguları}

"Okul öncesi öğretmen adaylarının sınıf seviyelerine göre fen eğitimine yönelik öz-yeterlikleri arasında anlamlı bir fark var mıdır?” birinci alt problemine göre, FÖÖ'nün sınıf düzeyleri arasında anlamlı farkın bulunup bulunmadığını belirlemek için yapılan Kruskal-Wallis testi verileri aşağıda sunulmuştur:

Tablo 2. FÖÖ için Kruskal-Wallis testi sonuçları

\begin{tabular}{ccccccc}
\hline & Sinıf Düzeyi & N & Sira Ortalamas1 & $\chi^{2}$ & sd & p \\
\hline ToplamFÖÖ & 1. Sinıf & 89 & 167,37 & & & \\
& 2. Sinıf & 114 & 184,02 & & & \\
& 3. Sinıf & 93 & 210,50 & 9,837 & 3 &, 020 \\
& 4. Sinıf & 88 & 209,88 & & & \\
& Toplam & 384 & & & & \\
\hline
\end{tabular}

Tablo 2'ye göre p değeri ,05'ten büyük olmadığı için "sınıf düzeyleri arasında anlamlı fark yoktur" hipotezi kabul edilmediğinden, grupların en az ikisinin ortalamaları arasında anlamlı fark vardır sonucuna varılmıştır. Hangi gruplar arasında anlamlı farkın olduğunu tespit etmek amacıyla MannWhitney U testleri yapılmış ve aşağıda özet tablo halinde sunulmuştur.

Tablo 3. FÖÖ için Mann-Whitney U testlerinin sonuçları

\begin{tabular}{ccccccc}
\hline Sinıf Düzeyleri & N & Sira Ortalamas1 & sd & $\chi^{2}$ & $p$ & Anlamlı Fark \\
\hline 1. Sinıf & 89 & 167,37 & 3 & 9,837 &, 02 & 1.sinıf - 3.sinıf \\
2. Sinıf & 114 & 184,02 & & & & 1. sinıf - 4.sınıf \\
3. Sinıf & 93 & 210,50 & & & & \\
4. Sinıf & 88 & 209,88 & & & & \\
\hline
\end{tabular}


Tablo 3'e göre 1. ve 3. siniflar arasında 3. sinıflar lehine; 1. ve 4. sinıflar arasinda da 4. siniflar lehine anlamlı farkın olduğu tespit edilmiştir.

\section{Araştırmanın İkinci Alt Problemine Ait Bulguları}

"Okul öncesi öğretmen adaylarının sınıf seviyelerine göre öğrenme yaklaşımlarının alt boyutları (Derinlemesine, Stratejik, Yüzeysel) arasında anlamlı bir fark var mıdır?" ikinci alt problemine göre, Derinlemesine alt boyutunun sınıf düzeyleri arasında anlamlı farkın bulunup bulunmadığını belirlemek için yapılan Kruskal-Wallis testi verileri aşağıda sunulmuştur:

Tablo 4. Derinlemesine alt boyutu için Kruskal-Wallis testi sonuçları

\begin{tabular}{ccccccc}
\hline & Sinıf Düzeyi & N & Sira Ortalamas1 & $\chi^{2}$ & sd & p \\
\hline Derinlemesine & 1. Sinıf & 89 & 221,83 & & & \\
& 2. Sinıf & 114 & 199,17 & & & \\
& 3. Sinıf & 93 & 176,99 & 11,883 & 3 &, 008 \\
4. Sinıf & 88 & 170,59 & & & \\
Toplam & 384 & & & & \\
\hline
\end{tabular}

Tablo 4'e göre $\mathrm{p}$ değeri, 05 'ten büyük olmadığı için "sınıf düzeyleri arasında anlamlı fark yoktur" hipotezi kabul edilmediğinden, grupların en az ikisinin ortalamaları arasında anlamlı fark vardır sonucuna varılmıştır. Hangi gruplar arasında anlamlı farkın olduğunu tespit etmek amacıyla MannWhitney U testleri yapılmış ve aşağıda özet tablo halinde sunulmuştur.

Tablo 5. Derinlemesine alt boyutu için Mann-Whitney U testlerinin sonuçları

\begin{tabular}{ccccccc}
\hline Sinıf Düzeyleri & N & Sira Ortalamas1 & sd & $\chi^{2}$ & p & Anlamlı Fark \\
\hline 1. Sinıf & 89 & 221,83 & 3 & 11,883 &, 008 & 1.sınıf -3 .sinif \\
2. Sinıf & 114 & 199,17 & & & & 1.sınıf -4 .sinıf \\
3. Sinıf & 93 & 176,99 & & & & \\
4. Sinıf & 88 & 170,59 & & & & \\
\hline
\end{tabular}

Tablo 5'e göre 1. ve 3. sinıflar arasinda 1. sinıflar lehine; 1. ve 4. sinıflar arasinda da yine 1. sinıflar lehine anlamlı farkın olduğu tespit edilmiştir.

Tablo 6. Stratejik alt boyutu için Kruskal-Wallis testi sonuçları

\begin{tabular}{ccccccc}
\hline & Sinıf Düzeyi & N & Sira Ortalamas1 & $\chi^{2}$ & sd & $\mathrm{p}$ \\
\hline Stratejik & 1. Sinıf & 89 & 221,28 & & & \\
& 2. Sinıf & 114 & 199,07 & & & \\
& 3. Sinıf & 93 & 165,51 & 12,488 & 3 &, 006 \\
4. Sinıf & 88 & 183,41 & & & \\
Toplam & 384 & & & & \\
\hline
\end{tabular}

Tablo 6'ya göre p değeri ,05'ten büyük olmadığı için "sınıf düzeyleri arasında anlamlı fark yoktur" hipotezi kabul edilmediğinden, grupların en az ikisinin ortalamaları arasında anlamlı fark vardır sonucuna varılmıştır. Hangi gruplar arasında anlamlı farkın olduğunu tespit etmek amacıyla MannWhitney U testleri yapılmış ve aşağıda özet tablo halinde sunulmuştur.

Tablo 7. Stratejik alt boyutu için Mann-Whitney U testlerinin sonuçları

\begin{tabular}{ccccccc}
\hline Sinıf Düzeyleri & N & Sira Ortalamas1 & sd & $\chi^{2}$ & $p$ & Anlamlı Fark \\
\hline 1. Sinıf & 89 & 221,28 & 3 & 12,488 &, 006 & 1.sinıf -3. sinıf \\
2. Sinıf & 114 & 199,07 & & & & 1.sinıf -4 .sinıf \\
3. Sinıf & 93 & 165,51 & & & & 2.sinıf -3. sinıf \\
4. Sinıf & 88 & 183,41 & & & & \\
\hline
\end{tabular}

Tablo 7'ye göre 1. ve 3. sinıflar arasinda 1. sinıflar lehine, 1. ve 4. siniflar arasinda da 1. siniflar lehine ve 2. ve 3. sınıflar arasında 2. sınıflar lehine anlamlı farkın olduğu tespit edilmiştir. 
Tablo 8. Yüzeysel alt boyutu için Kruskal-Wallis testi sonuçları

\begin{tabular}{ccccccc}
\hline & Sinıf Düzeyi & N & Sira Ortalamas1 & $\chi^{2}$ & sd & p \\
\hline Yüzeysel & 1. Sinıf & 89 & 202,94 & & & \\
& 2. Sinıf & 114 & 201,64 & & & \\
& 3. Sinıf & 93 & 178,69 & 3,442 & 3 &, 328 \\
& 4. Sinıf & 88 & 184,68 & & & \\
Toplam & 384 & & & & \\
\hline
\end{tabular}

Tablo 8'e göre p değeri ,05'ten küçük olmadığı için "sınıf düzeyleri arasında anlamlı fark yoktur" hipotezi kabul edildiğinden, grupların ortalamaları arasında anlamlı fark yoktur sonucuna varılmıştır.

\section{Araştırmanın Üçüncü Alt Problemine Ait Bulguları}

"Okul öncesi öğretmen adaylarının sınıf seviyelerine göre öğrenme-öğretme ortamına yönelik algıları arasında anlamlı bir fark var mıdır?" üçüncü alt problemine göre, ÖÖOÖ’nün sinıf düzeyleri arasında anlamlı farkın bulunup bulunmadığını belirlemek için yapılan İlişkisiz Örneklemler için Tek Yönlü Varyans Analizi testi verileri aşağıda sunulmuştur:

Tablo 9. ÖÖOÖ için İlişkisiz Örneklemler için Tek Yönlü Varyans Analizi testi sonuçları

\begin{tabular}{cccccccccc}
\hline Grup & $\mathrm{N}$ & $\bar{X}$ & ss & Var. K. & KT & sd & KO & F & p \\
\hline 1. Sinıf & 89 & 99,54 & 15,50 & G.Aras1 & 5380,08 & 3 & 1793,36 & & \\
2. Sinıf & 114 & 96,40 & 16,13 & G. İçi & 85181,88 & 380 & 224,16 & & \\
3. Sinıf & 93 & 93,94 & 11,82 & Toplam & 90561,96 & 383 & & 8,000 & \multirow{2}{*}{000} \\
4. Sinıf & 88 & 88,94 & 15,82 & & & & & & \\
Top. & 384 & 94,82 & 15,38 & & & & & & \\
\hline
\end{tabular}

Tablo 9'da yer alan F değerinin anlamlılık test sonucuna göre, $\mathrm{p}$ değeri ,05'ten büyük olmadığı için "sınıf düzeyleri arasında anlamlı fark yoktur" şeklindeki yokluk hipotezi reddedildiğinden, grupların en az ikisinin ortalamaları arasında anlamlı fark vardır sonucuna varılmıştır. Hangi gruplar arasında anlamlı farkın olduğunu tespit etmek amacıyla çoklu karşılaştırma testlerinden Tukey Testi sonuçları tablo halinde sunulmuştur.

Tablo 10. ÖÖOÖ için çoklu karşılaştırma testi (Tukey testi) sonuçları

\begin{tabular}{|c|c|c|c|c|c|c|}
\hline \multirow{2}{*}{$\begin{array}{c}\text { (I) } \\
\text { SınıfDüzeyı }\end{array}$} & \multirow{2}{*}{$\begin{array}{c}(\mathrm{J}) \\
\text { SinıfDüzeyi }\end{array}$} & \multirow{2}{*}{$\begin{array}{c}\text { Ort.lar Arasi } \\
\text { Fark }\end{array}$} & \multirow[b]{2}{*}{ Std. Hata } & \multirow[b]{2}{*}{$\mathrm{p}$} & \multicolumn{2}{|c|}{ \%95 Olasılıkla Güven Ara } \\
\hline & & & & & Alt Sinır & Üst Sinır \\
\hline \multirow[t]{3}{*}{ 1. Sinıf } & 2. Sinif & 3,14 & 2,12 & ,450 & $-2,33$ & 8,60 \\
\hline & 3. Sinif & 5,60 & 2,22 & 058 &,- 13 & 11,33 \\
\hline & 4. Sinif & $10,60 *$ & 2,25 & ,000 & 4,79 & 16,40 \\
\hline \multirow[t]{2}{*}{ 2. Sinif } & 3. Sinif & 2,47 & 2,09 & 640 & $-2,93$ & 7,87 \\
\hline & 4. Sinif & $7,46^{*}$ & 2,12 & 003 & 1,98 & 12,94 \\
\hline 3. Sinif & 4. Sinif & 4,99 & 2,23 & 114 &,- 75 & 10,74 \\
\hline
\end{tabular}

*. 0.05 düzeyinde anlamlı fark.

Tablo 10'a göre 1. ve 4. sinıflar arasinda 1. sinıflar lehine; 2. ve 4. sinıflar arasinda da 2. sinıflar lehine anlamlı farkın olduğu tespit edilmiştir.

\section{Araştırmanın Dördüncü Alt Problemine Ait Bulguları}

"Okul öncesi öğretmen adaylarının fen eğitimine yönelik öz-yeterlikleri ile öğrenme-öğretme ortamına yönelik algıları ve öğrenme yaklaşımları arasında anlamlı bir fark var mıdır?" dördüncü alt problemine göre, ölçekler arasında ilişkinin bulunup bulunmadığını belirlemek için yapılan korelasyon analizi testi verileri Tablo 11'de sunulmuştur:

Tablo 11. FÖÖ, ÖYÖ ve ÖÖOÖ arasındaki korelasyon analizi sonuçları

\begin{tabular}{clccc}
\hline & ToplamFÖÖ & ToplamÖYÖ & ToplamÖÖOÖ \\
\hline \multirow{2}{*}{ ToplamFÖÖ } & Pearson Korelasyonu & 1 &, $376^{* *}$ &, $227^{* *}$ \\
& $\mathrm{p}(2$-uçlu) & &, 000 &, 000 \\
& $\mathrm{~N}$ & 384 & 384 & 384 \\
\hline
\end{tabular}




\begin{tabular}{llccc}
\hline ToplamÖYÖ & Pearson Korelasyonu &, $376^{* *}$ & 1 &, $528^{* *}$ \\
& $\mathrm{p}(2-\mathrm{uçlu})$ &, 000 & &, 000 \\
& $\mathrm{~N}$ & 384 & 384 & 384 \\
\hline ToplamÖÖOÖ & Pearson Korelasyonu &, $227^{* *}$ &, $528^{* *}$ & 1 \\
& $\mathrm{p}(2$-uçlu) &, 000 &, 000 & 384 \\
& $\mathrm{~N}$ & 384 & 384 & 384 \\
\hline
\end{tabular}

**. 0.01 düzeyinde anlamlı ilişki (2-uçlu).

Korelasyon analizi sonucuna göre ,01 anlamlılık düzeyinde, FÖÖ ile ÖYÖ arasında, FÖÖ ile ÖÖOÖ arasında ve ÖYÖ ile ÖÖOÖ arasında pozitif yönlü ve anlamlı düzeyde ilişki olduğu tespit edilmiştir.

\section{TARTIŞMA VE SONUÇLAR}

Araştırmanın bulguları dikkate alındığında, okul öncesi 3. ve 4. sınıf öğretmen adaylarının fen özyeterliklerinin 1.sınıf öğretmen adaylarına oranla daha yüksek olduğu bulunmuştur. Bu durumun ana sebebi lisans eğitimleri sırasında 3. sınıfin güz döneminde almış oldukları "Okul Öncesinde Fen Eğitimi" dersi ve bu ders kapsamında almış oldukları eğitim olabilir. Dersin haftada 4 saat olarak ve 2 saat teorik ve 2 saat uygulamalı bir ders olduğu göz önünde bulundurulduğunda 3. ve 4. sınıf öğretmen adaylarının 1. ve 2. sinıflara oranla 56 saatlik bir fen eğitiminin sonucunda öz-yeterliklerinin artmış olduğu söylenebilir. Nitekim Alabay (2006) ve Şenol (2012) da yapmış oldukları çalışmalarında okul öncesi öğretmen adaylarından 1. sınıfta olanların fen öz-yeterliklerinin diğer sınıf düzeylerine göre daha düşük olduğunu tespit etmişlerdir. Ekinci-Vural ve Hamurcu (2008) da yine benzer şekilde 3. sinıfta öğrenim görmekte olan okul öncesi öğretmen adaylarının 1. sınıfta öğrenim görenlere oranla anlamlı derecede fen öz-yeterliklerinin yüksek olduğunu bulmuştur. Benzer şekilde Büyüktanır (2014) da yapmış olduğu çalışmada 3. ve 4. sınıf öğretmen adaylarının fen öz-yeterliğinin 1. ve 2. sınıf öğretmen adaylarına oranla daha yüksek olduğunu bulmuştur ve bunun sebebinin benzer şekilde öğretmen adaylarının 3. sınıfta almış oldukları "Okul öncesinde Fen Eğitimi”" dersinin olabileceğini belirtmiştir. Ayrıca Toptaş ve Gözel (2017) de benzer sonuçlara ulaşarak sınıf seviyesinin arttıkça öz-yeterlik inancının arttığını tespit etmiştir.

Araştırmadan elde edilen bir diğer sonuç da okul öncesi öğretmen adaylarının öğrenme yaklaşımlarının "derinlemesine" alt boyutunun 1. sinıflar lehine anlamlı derecede yüksek olduğu bulunmuştur. Sınıf seviyesi arttıkça derinlemesine öğrenme yaklaşımlarını tercih edenlerin sayısı azalmaktadır. Ayrıca öğrenme yaklaşımlarının "stratejik" alt boyutu için de yine 1. ve 2. sınıflar lehine anlamlı fark çıkmıştır. Öğrenme yaklaşımlarının "yüzeysel" alt boyutu için sınıf seviyelerine göre anlamlı bir farklılaşma görülmemiştir. $\mathrm{Bu}$ konuda yapılmış çalışmalar incelendiğinde çok farklı sonuçların olduğu görülmektedir. Örneğin bazı çalışmalarda sınıf seviyeleri arttıkça derinlemesine öğrenme yaklaşımlarını tercih edenlerin sayısının arttığı bulunurken (Zeegers, 2001; Sezgin-Selçuk, Çalışkan ve Erol, 2007), bazı çalışmalarda sınıf seviyelerine göre farklılaşma bulunamamış (Ekinci, 2008), bazılarında ise bu çalışmada olduğu gibi sınıf seviyeleri arttıkça derinlemesine öğrenme yaklaşımını tercih edenlerin sayısının azaldığı sonucuna ulaşılmıştır (Gow, Kember ve Cooper, 1994; Tural-Dinçer ve Akdeniz, 2008; Büyüktanır, 2014). Bunun sebebini Tural-Dinçer ve Akdeniz (2008) öğretmen adaylarının heyecanının yıllar geçtikçe kaybolmasına bağlamışlardır. Öğrenme yaklaşımlarından yüzeysel alt boyut için sınıf seviyelerine göre anlamlı bir farklılık göstermemesi ise ilginçtir. Halbuki öğretmen adaylarının sınıf seviyeleri arttıkça derinlemesine öğrenme yaklaşımlarını daha çok tercih etmeleri ve yüzeysel öğrenme yaklaşımlarını daha az tercih etmeleri beklenirken (Büyüktanır, 2014), öğretmen adaylarının her sınıf seviyesinde yüzeysel öğrenme yaklaşımına bakış açıları benzerdir. Bununla beraber stratejik öğrenme yaklaşımları da yine 1. ve 2. sınıf öğretmen adaylarında daha çok tercih edilmiştir. Stratejik öğrenme yaklaşımları başarı odaklı oldukları için öğretmen adayları ilk yıllarda buna daha çok önem verirlerken, ilerleyen yıllarda sınavlara daha fazla önem vermeye başlamışlardır. Öğretmen adayları lisans eğitimine kadar her kademenin sonunda bir sınava girdikleri için ve lisans eğitimlerinin sonunda da yine bir sınava girecekleri için daha yüzeysel ve ezbere yönelik bir öğrenme yaklaşımını tercih etmeleri normaldir. Buradan yola çıkarak üniversite eğitiminin öğrencilerin derinlemesine öğrenmeye yönelimlerini artırmada başarısız olduğu sonucuna ulaşılabilir (Ekinci, 2008). Okul öncesi öğretmenliğinde okuyan öğrencilerin üniversiteye giriş puanlarının oldukça yüksek olduğu göz önünde 
bulundurulduğunda aslında onların derinlemesine öğrenmeye daha fazla önem vermeleri beklenir. Yani konular arasındaki bağlantıları daha net görebilen üst düzey düşünme becerilerini kullanabilen bireyler olmaları beklenir. Ancak lisans programını bitirdikten sonra da atanabilirliği yüksek bir bölüm olması sebebiyle öğretmen adaylarının derinlemesine öğrenmeye çabalamaktan ziyade, sınavları bir şekilde geçip asıl hedefin atanabilmek olduğu anlaşılmaktadır. Bu da onların neden yüzeysel öğrenmeye daha yakın durduklarını açıklamaktadır.

Araştırmanın ulaştığı bir diğer sonuç da, okul öncesi öğretmen adaylarının sınıf seviyelerine göre ögrrenme-öğretme ortamına yönelik algıları arasında 1. ve 2. sınıflar lehine farkın bulunması ve sınıf seviyeleri arttıkça öğretmen adaylarının öğrenme-öğretme ortamına yönelik algı puanlarının gittikçe düşmesidir. Bu durum öğretmen adaylarının sınıf seviyelerinin artmasıyla birlikte öğrenme-öğretme ortamına yönelik algılarının olumsuz etkilendiğini göstermektedir. Bu durumu Ekinci (2008) öğretmen adaylarının beklentilerinin karşılanamaması ya da öğretmen adaylarının öğrenme-öğretme konusundaki farkındalıklarının artmasıyla ilişkilendirmiştir. Ayrıca okul öncesi öğretmen adaylarının da yıllar geçtikçe ilgilerinin okulu tamamlamaya ve atanarak bir kurumda göreve başlamaya odaklandığı da söylenebilir.

Araştırmanın dördüncü alt probleminden elde edilen sonuç ise okul öncesi öğretmen adaylarının fen eğitimine yönelik öz-yeterlikleri ile öğrenme yaklaşımlarını tercih etmeleri arasında orta düzeyde pozitif yönlü bir ilişkinin olmasıdır. Bu konuda yapılmış diğer çalışmalarda da öz-yeterlik ile öğrenme yaklaşımları arasında pozitif bir ilişkinin varlığından bahsedilmiştir (Kızılgüneş, 2007). Fen öz-yeterliği yüksek olan öğretmenlerin öğretmeye daha istekli oldukları ve her türlü etkinlik için daha mücadeleci oldukları bilinen bir gerçektir (Bıkmaz, 2004). Ancak fen öz-yeterliği düşük olan öğretmenlerin fen etkinlikleri için yeterli zamanı ayırmadıkları görülmüștür (Appleton, 1992; Cho, Kim ve Choi, 2003). Bu da dolaylı olarak öğretimde daha yüzeysel bir yaklaşım benimseyecekleri şeklinde yorumlanabilir. Ayrıca okul öncesi öğretmen adaylarının fen eğitimine yönelik öz-yeterlikleri ile öğrenme-öğretme ortamına yönelik algıları arasında da öğrenme yaklaşımlarına oranla daha düşük yine pozitif yönlü bir ilişki bulunmuştur. Okul öncesi öğretmen adaylarının öğrenme yaklaşımlarını tercih etmeleri ise öğrenme-öğretme ortamına yönelik algıları ile daha yüksek oranda ilişkili çıkmıştır. Bu sonuç literatürde yapılmış diğer araştırma sonuçlarıyla benzerlik göstermektedir. Öğrenme-öğretme ortamının daha özgürlükçü ve iş yükünün az olduğu ortamlardaki öğrencilerin daha derinlemesine öğrenme yaklaşımlarını tercih ettikleri, öğrenme-öğretme ortamında ağır iş yükü bulunan öğrencilerin ise daha yüzeysel öğrenme yaklaşımlarını tercih ettikleri bulunmuştur (Ramsden ve Entwistle, 1981). Okul öncesi ögretmen adaylarının da fen öz-yeterlik inançları arttıkça tercih edecekleri öğrenme yaklaşımlarının da yüzeysel öğrenme yaklaşımından uzaklaşacağı düşünülmektedir. Çünkü kendini alanda yeterli hisseden bir öğretmenin daha öğrenci merkezli bir yaklaşımı benimseyerek, daha kavramsal bir öğrenmeye yer vereceği düşünülmektedir (Britner ve Pajares, 2006).

\section{ÖNERILER}

Araştırmadan elde edilen sonuçlara bakılarak öğretmen adaylarının öğrenme yaklaşımlarından derinlemesine alt boyutu yıllar geçtikçe tercih etmeyerek daha çok yüzeysel boyuta yönelmeleri; üniversitelerde süreç odaklı bir yaklaşımın benimsenmesi gerektiğini düşündürmektedir. Eğitimin sınav odaklı olmasından ziyade süreç odaklı bir yaklaşımla yürütülmesi öğretmen adaylarının daha derinlemesine öğrenmesine sebep olacak ve bu da dolaylı olarak öz-yeterliklerini artırmaya katkıda bulunacaktır. Ayrıca yine üniversitelerde verilen eğitimin yaratmış olduğu iş yükü de öğretmen adaylarının öğrenme yaklaşımlarını etkilemekte, onların daha yüzeysel öğrenme yaklaşımlarını tercih etmelerine sebep olmakta ve bu da yine öz-yeterlik inançlarını olumsuz etkilemektedir. Bu sebeple iş yükünün hafifletilmesi veya lisans eğitimlerinin sonunda öğretmen adaylarının girecekleri sınav kaldırılamıyorsa eğer bu sınavla paralel bir eğitimin sağlanması iş yükünü hafifletici bir etken olacaktır. Ayrıca öğretmen adaylarının öz-yeterlik inançları onların mesleki gelişimlerini ve performanslarını doğrudan etkileyeceği için hizmet öncesi ve hizmet içi programlar hazırlanarak uygulanabilir. 
Bilgilendirme / Acknowledgement:

1-Araştırmacıların katkı oranları eşittir.

2-Makalenin yazarları arasında çıkar çatışması bulunmamaktadır.

3-Araştırma verileri 2020 yılı öncesi toplanmış ve kullanılmıştır.

\section{KAYNAKÇA}

Akçöltekin, A. (2019). Bilimsel araştırmalara yönelik öğretmen öz yeterlilik ölçeğinin geliştirilmesi. Kastamonu Eğitim Dergisi, 27(6), 2713-2727.

Alabay, E. (2006). İlköğretim okulöncesi öğretmen adaylarının fen ile ilgili öz yeterlik inanç düzeylerinin incelenmesi. Yeditepe Üniversitesi Eğitim Fakültesi Dergisi, 2(1).

Appleton, K. (1992). Discipline knowledge and confidence to teach science: Self-perceptions of primary teacher education students. Research in Science Education, 22(1), 11-19.

Ayvac1, H. Ş., Devecioğlu, Y. ve Yiğit, N. (2002). Okul öncesi öğretmenlerinin fen ve doğa etkinliklerindeki yeterliliklerinin belirlenmesi. 5. Ulusal Fen Bilimleri ve Matematik Eğitimi Kongresinde sunulmuş bildiri, 16-18 Eylül, ODTÜ, Ankara, Türkiye.

Azar, A. (2010). In-service and pre-service secondary science teachers' self-efficacy beliefs about science teaching. Educational Research and Reviews, 5(4), 175-188.

Bahadır, F., Dikmen, M., Akmençe, A. E., Şimşek, M. ve Tuncer, M. (2019). Okul öncesi öğretmenlerinin okul öncesi eğitim programındaki fen etkinliklerine yönelik öz-yeterlik inançlarının belirlenmesi. The Journal of Educational Reflections, 3(1), 28-41.

Bahar, H. H. (2019). Sınıf öğretmen adaylarında akademik öz-yeterlik algısının akademik başarıyı yordama gücü. İlkögretim Online, 18(1), 149-157.

Berkant, H. G. ve Ekici, G. (2007). Sınıf öğretmeni adaylarının fen öğretiminde öğretmen öz-yeterlik inanç düzeyleri ile zeka türleri arasındaki ilişkinin değerlendirilmesi. Çukurova Üniversitesi Sosyal Bilimler Enstitüsü Dergisi, 16(1), 113-132.

Biggs, J. (1987). The study process questionnaire spq. Manual. Hawthorn, Vic.: Australian Council of Educational Research.

Biggs, J. (1999). Teaching for quality learning at university. London: Open University Press.

Bikmaz, F. H. (2004). Validity and reliability study of self-efficacy belief scale in science teaching of primary teachers. Journal of National Education, 161. 11 Ocak 2016 tarihinde http://dhgm.meb.gov.tr/yayimlar/dergiler/Milli_Egitim_Dergisi/161/bikmaz.htm adresinden erişildi.

Britner, S. L. and Pajares, F. (2006). Sources of science self-efficacy beliefs of middle school students. Journal of Research in Science Teaching, 43(5), 485-499.

Büyüköztürk, Ş., Kılıç Çakmak, E., Akgün, Ö. E., Karadeniz, Ş. ve Demirel, F. (2009). Bilimsel araştırma yöntemleri. Ankara: Pegem Akademi.

Büyüktanır, A. (2014). Okul öncesi ögretmen adaylarının fen eğitimine yönelik öz yeterlikleri başarı amaç oryantasyonları ve öğrenme yaklaşımları arasındaki ilişkinin incelenmesi. Yayınlanmamış yüksek lisans tezi, Gazi Üniversitesi, Ankara.

Cho, H., Kim, J., and Choi, D. H. (2003). Early childhood teachers' attitudes toward science teaching: A scale validation study. Educational Research Quarterly, 27(2), 33-42.

Cohen, L., and Manion, L. (1989). Research methods in education (4th Ed.). New York: Routledge. 
Cohen, L., Manion, L., and Morrison, K. (2005). Research methods in education (5th Ed.). London, New York: Routledge Falmer.

Compeau, D. R., and Higgins, C. A. (1995). Computer selfefficacy: Development of a measure and initial test. MIS Quaterly, 19(2), 189-211.

Çelik, O. (2019). Illkokul ve ortaokul ögretmenlerinin öz yeterlilikleri ile sinıf yönetimi becerileri arasındaki ilişkinin incelenmesi. Yayınlanmamış yüksek lisans tezi, İstanbul Sabahattin Zaim Üniversitesi, İstanbul.

Diseth, A. (2007). Student evaluation of teaching, approaches to learning and academics achievement. Scandinavian Jouranl of Educational Research, 51(2), 185-204.

Dönmez Usta, N. ve Ültay, N. (2017). Okul öncesi öğretmenlerinin fen ve doğa etkinliklerini uygulamadaki yeterliliklerinin belirlenmesi. Avrasya Sosyal ve Ekonomi Araştırmaları Dergisi, 4(9), 19-30.

Drew, C. J., Hardman, M. L., and Hart, A. W. (1996). Designing and conducting research: Inquiry in education and social science (2nd ed.). Boston: Allyn and Bacon.

Ekici, G. (2008). Sınıf yönetimi dersinin öğretmen adaylarının öğretmen öz-yeterlik algı düzeyine etkisi. Hacettepe Eğitim Fakültesi Dergisi, 35, 98-110.

Ekinci, N. (2008). Üniversite ögrencilerinin ögrrenme yaklaşımlarının belirlenmesi ve öğrenme öğretme süreci değiş̧kenleriyle ilişkileri. Yayımlanmamış doktora tezi, Hacettepe Üniversitesi, Ankara.

Ekinci-Vural, D. ve Hamurcu, H. (2008). Okul öncesi öğretmen adaylarının fen öğretimi dersine yönelik öz-yeterlik inançları ve görüşleri. İlköğretim Online, 7(2), 456-467.

Fry, H., Ketteridge, S. and Marshall, S. (Eds.). (2003). A handbook for teaching and learning in higher education. London: Kogan Page.

Goddard, R. D., Hoy, W. K., and Woolfolk-Hoy, A. W. (2004). Collective efficacy beliefs: Theoretical developments, empirical evidence, and future directions. Educational Researcher, 33(3), 3-13.

Gow, L., Kember, D., and Cooper, B. (1994). The teaching context and approaches to study of accountancy students. Issues in Accounting Education, 9(1), 118-130.

Gül, Ş. ve Özay Köse, E. (2017). Fen ve matematik branş öğretmenlerinin eğitim araştırmalarına yönelik tutumları. Yüzüncü Yll Üniversitesi Eğitim Fakültesi Dergisi, 14(1), 700-725.

Gürcan, A. (2005). Bilgisayar özyeterliği algısı ile bilişsel öğrenme stratejileri arasındaki ilişki. Eğitim Araştırmaları, 19, 179-193.

Karasar, N. (2007). Bilimsel araştırma yöntemi. İzmir: Nobel Yayınevi.

Kember, D., ve Leung, D. Y. P. (1998). Influences upon students' perceptions of workload. Educational Psychology, 18(3), 293-308.

Khan, A., Fleva, E., and Qazi, T. (2015). Role of self-esteem and general self-efficacy in teachers' efficacy in primary schools. Psychology, 6, 117-125.

Khodarahimi, S. (2010). General self-efficacay and worry in an Iranian adolescents and youths samples. Educational Research, 1(2), 015-020.

Kızılgüneş, B. (2007). Predictive influence of students achievement motivation, meaningful learning approach and epistemological beliefs on classification concept achievement. Unpublished master dissertation, Middle East Technical University, Ankara.

Kotaman, H. (2008). Özyeterlilik inancı ve öğrenme performansının geliştirilmesine ilişkin yazın taraması. Uludă Üniversitesi Ĕ̈itim Fakültesi Dergisi, 21(1), 111-133. 
Ocak, G. ve Karakuş, G. (2019). Öğretmen adaylarının dijital okuryazarlık öz-yeterlilik becerilerinin farklı değişkenler açısından incelenmesi. Afyon Kocatepe Üniversitesi Sosyal Bilimler Dergisi, 21(1). 129-147.

Orkunoğlu, Y. M., (2016). Okul öncesi ögretmenlerinin fen ögretimine yönelik tutumlart ile öz yeterlilik düzeyleri arasındaki ilişkinin incelenmesi (İstanbul ili Ataşehir ilçesi örneği). Yayınlanmamış yüksek lisans tezi, Yeditepe Üniversitesi, İstanbul.

Özbey, S., ve Alisinanoğlu, F. (2008). Identifying the general ideas attitudes and expectations pertaining to science activities of the teachers employed in preschool education. Journal of Turkish Science Education, 5(2), 82-94.

Ramsden, P. (2000). Learnig to teaching in higher education. London: Newyork Routhladge Falmer.

Ramsden, P., and Entwistle, N. J. (1981). Effects of academic departments on students approaches to studying. British Journal of Educational Psychology, 51, 368-83.

Sezgin-Selçuk, G., Çalışkan, S. ve Erol, M. (2007). Fizik öğretmen adaylarının öğrenme yaklaşımlarının değerlendirilmesi. Gazi Eğitim Fakültesi Dergisi, 27(2), 25-41.

Skaalvik, E. M., and Skaalvik, S. (2010). Teacher self-efficacy and teacher burnout: A study of relations. Teaching and Teacher Education: An International Journal of Research and Studies, 26(4), 1059-1069.

Şenol, F. B. (2012). Okul öncesi öğretmen adaylart ile okul öncesi öğretmenlerinin mesleğine yönelik öz yeterlik inançlarının karşılaş̧ırılması. Yayınlanmamış yüksek lisans tezi, Afyon Kocatepe Üniversitesi, Afyon.

Toptaş, V. ve Gözel, E. (2017). Sınıf öğretmeni adaylarının özyeterlik ile matematiksel problem çözmeye yönelik inançları. Kırıkkale Üniversitesi Sosyal Bilimler Dergisi, 7(2), 439-460.

Tschannen-Moran, M., Woolfolk-Hoy, A., and Hoy, W. K. (1998). Teacher efficacy: Its meaning and measure. Review of Educational Research, 68, 202-248.

Tural-Dinçer, G., and Akdeniz, A. R. (2008). Examining learning approaches of science student teachers according to the class level and gender. US-China Education Review, 5(12), 54-59.

Ültay, E. ve Can, M. (2015). Okul öncesi öğretmen adaylarının 1sı ve sıcaklık konusundaki kavramsal bilgilerinin belirlenmesi. Karadeniz Sosyal Bilimler Dergisi, 7(Hüseyin Hüsnü Tekışık Özel Say1s1-1), 179-203.

Ültay, E. ve Ültay, N. (2015). Okul öncesi öğretmen adaylarının bazı fen kavramları hakkındaki kavramsal bilgilerinin kesitsel olarak incelenmesi. Uluslararası Sosyal Araştırmalar Dergisi, 8(41), 1046-1051.

Ültay, N., Ültay, E. ve Çilingir, S. K. (2018). Okul öncesi öğretmenlerinin fen konularındaki uygulamalarının incelenmesi. Atatürk Üniversitesi Sosyal Bilimler Enstitüsü Dergisi, 22(Özel Say1), 773-792.

Ültay, N., Ültay, E. ve Çilingir, S. K. (2019). Okul öncesi öğretmen adaylarının çevreye karş1 tutumlarının ve çevre bilgi seviyelerinin bazı değişkenler açısından incelenmesi. Akdeniz Ĕ̈itim Araştırmaları Dergisi, 13(28), 173-185.

Vural, D. E. ve Hamurcu, H. (2008). Okul öncesi öğretmen adaylarının fen öğretimi dersine yönelik özyeterlik inançları ve görüşleri. İlkögretim Online, 7(2), 456-467.

Woolfolk-Hoy, A., and Spero, R. B. (2005). Changes in teacher efficacy during the early years of teaching: A comparison of four measures. Teaching and Teacher Education, 21, 343-356.

Zeegers, P. (2001). Approaches to learning in science: A longitudinal study. British Journal of Educational Psychology, 71, 115-132. 